\title{
Manuscriptology: Relevance for Ayurveda Research Scholar
}

\author{
Review Article
}

\section{Sreeja KG ${ }^{*}$, Jayashankar Mund ${ }^{2}$, Vishwanathan Nambootiri ${ }^{3}$, Leena P Nair ${ }^{4}$}

\author{
1. PG Scholar, 2. Professor and HOD, 4. Lecturer \\ Department of Samhita and Siddhantha, Amrita School of Ayurveda, Clappana (PO), Kollam, Kerala \\ 3. Research Guide, MG University, Kottayam
}

\begin{abstract}
Manuscripts are the treasure of wisdom passed from generation to generation. The art of writing emerged as a way of preserving knowledge that was previously transmitted orally from one generation to the next. Ayurveda developed as a result of the accumulated wisdom and practical experiences of many generations. The knowledge gained by ancient seers of Ayurveda were passed generations through the Manuscripts. Still thousands of valuable unpublished Ayurveda manuscripts are available in Government agencies which can immensely contribute in the development of system. Government of India gives a great importance to procure, preserve and to publish manuscripts. Kerala has exceptionally rich Ayurveda tradition and collection of Manuscripts which required special attention by the Government and from the scholars. The preserved Manuscripts are the invaluable treasure of knowledge which can be utilized for the well being of present generation as well as to pass on to the next generation. This study focuses on an introduction to manuscripts in Indian context with special reference to Kerala and discuss the importance of preserving and conserving manuscripts especially for an Ayurvedic research scholar.
\end{abstract}

Keywords: Manuscripts, Ayurveda, Manuscript preservation, Ayurvedic Manuscripts in Kerala, Conserving manuscripts, Traditional Knowledge.

\section{Introduction}

In prehistoric times, advices and knowledge were passed from generation to generation verbally. The development of writing enabled the knowledge to be stored and communicated (1). A knowledge based hand written composition on paper, palm leaf, birch bark, cloth, metal, or any other material that has significant scientific, historical, philosophical or aesthetic value is called manuscript (2). Manuscriptology is defined as that branch of science which imparts training in reading and understanding of ancient manuscripts. It also specializes in procurement, preservation and documentation of various kinds of manuscripts (1).

The Antiquities and Art Treasures Act, 1972 (3) lays down the legal framework for custody of manuscripts. Antiquities, defined under the Act include "any manuscript, record or other document which is of scientific, historical, literary or aesthetic value and which has been in existence for not less than seventy-five years." If this definition is taken into consideration, a manuscript means a hand written document which has scientific, historical, literary or

\footnotetext{
*Corresponding Author:

Sreeja KG

PG scholar,

Department of Samhita and Siddhantha,

Amrita School of Ayurveda, Clappana (PO),

Kollam, Kerala

Mobile No. +91-9495625104

E-mail: drsreejagnair@gmail.com
}

aesthetic value and which is at least seventy-five year old.

The unique pool of knowledge available in many manuscripts is under threat. So effective research projects should be launched and emphasis is to be given on the conservation and publication of knowledge available in those manuscripts.. This article focuses on an introduction to Ayurveda manuscripts in Indian context, with special reference to Kerala and discusses the importance of preservation and conservation of manuscripts especially for an Ayurvedic research scholar which is the need of hour.

\section{Aims and Objectives of the study}

1. To give an Introduction to manuscript history of India along with its present status.

2. To explore the importance of manuscript collection and preservation in the context of Ayurveda

3. To learn the Ayurvedic manuscript tradition of Kerala.

To explore the importance of collection and preservation of manuscript for an Ayurvedic scholar.

\section{Manuscripts in India}

Manuscripts are the treasures of wisdom and knowledge and is had a rich cultural and scientific heritage, India has a rich collection of manuscripts among the world. The manuscripts are written in different languages and scripts and in different materials like palm leaf, birch bark, cloth, stone etc (4). Most of the manuscripts are written in Sanskrit language (5). As per one of the surveys made by Dr. S. 
C. Biswas and Mr. M. K. Prajapati on behalf of INTACH (Indian National Trust for Art and Cultural Heritage) during 1988-90 and on the basis of scrutiny of about 1100 printed catalogues and hand lists belonging to 70 libraries, institutions and individuals, the following estimates were made: (6)

\section{Table 1: Number of Manuscripts in India}

\begin{tabular}{|l|l|r|}
\hline 1 & $\begin{array}{l}\text { Total number of manuscripts in India } \\
\text { Sanskrit } 67 \% \\
\text { Other Indian Languages 25\% } \\
\text { Arabic/Persian/Tibetan } 8 \%\end{array}$ & \\
\hline 2 & $\begin{array}{l}\text { Indian manuscripts available in } \\
\text { European countries }\end{array}$ & 60,000 \\
\hline 3 & Indian manuscripts in South Asia and & 150,000 \\
\hline 4 & Number of manuscripts recorded in & $1,000,000$ \\
\hline
\end{tabular}

The National Mission for Manuscripts [NAMAMI], New Delhi provides a conservative figure of seven million manuscripts in India, and its database is approaching 3.2 million records (7). The late Prof. David Pingree, basing his count on a lifetime of academic engagement with Indian manuscripts, estimated that there were thirty million manuscripts, if one counted both those in public and government libraries, and those in private collections (8). A huge collection of Indian manuscripts are also available in foreign countries especially in Europe, UK and USA (9). Many of these manuscripts are catalogued but still many are yet to be published or catalogued.

In India, the government is now keen in protecting the manuscripts and both Central and State governments have many projects and activities in these connections. Presently the nodal agency for manuscripts preservation and collection in India is the National Mission of Manuscripts (NAMAMI). NAMAMI is an autonomous organization under Ministry of Culture, Government of India, established to survey, locate and conserve Indian manuscripts, with an aim to create national resource base for manuscripts, for enhancing their access, awareness and use for educational purposes. The Mission was initiated in February 2003, by the Ministry of Tourism and Culture, Government of India and Indira Gandhi National Centre for the Arts (IGNCA) is the nodal agency for the execution of this project. It creates bibliographic databases of Indian manuscripts and is involved in the conservation and preservation of the manuscripts. At present the mission does have 50 manuscripts conservation centers (10). Other than these centers many others Oriental libraries are also working across India for the preservation and conservation of manuscripts. Huge collections of Manuscripts are preserved in these libraries. For example the Library of Tibetan Works and Archives, Dharamsala, Himachal Pradesh, which only started publishing its catalogues in 2003, has an estimated 80, 000 manuscripts (7). Sampurnanand Sanskrit
Visvavidyalaya, Varanasi has in excess of 125,000 manuscripts. There are about 59,000 manuscripts in the Sarasvati Mahal Library in Thanjavur and more than 73,000 manuscripts in Oriental Research Institute Library at Thiruvananthapuram.

\section{Ayurveda and Manuscripts}

Ayurveda is one of the oldest systems of medicine which was prominent in ancient India. Ayurveda developed as a result of the accumulated wisdom of many generations. Ayurveda has a hoary past and its roots can be traced back to pre-historic times. The remnants obtained from Harappa and Mohenjodaro include Ayurvedic medicines like Krishnagola (Shilajatu) and Harinashringa which reveal that even at the time of Indus Valley civilization (4-3 millennium B.C.) Ayurvedic medicines were in use (11). References to Ayurveda can also be observed in the Vedas and the Puranas. Among the Vedas it is the Atharvaveda, which gives an exhaustive detail of Ayurveda. Early inscriptions like those of Ashoka (3rd century B.C.) too indicate the popularity of this medical system.

In ancient period the medicinal knowledge of Ayurveda was not properly documented and the passing of such information was mainly from mouth to ear. The art of writing emerged as a way of preserving knowledge that was previously transmitted orally from one generation to the next. Writing in the form of manuscripts, inscriptions, and coins was used to store information for a longer time. The wisdom and knowledge earned by the Ayurveda practitioners of that time period were passed on to generations through manuscripts so that the knowledge and tradition will not be destroyed. The knowledge of Ayurveda available at present era is derived from such sources.

The earliest Ayurveda manuscripts, which are available now, are the Bower manuscripts (3rd century A.D.). Bower manuscripts were traced in 1890 by the British Lieutenant Bower from Kuchiar in Chinese Turkistan.(11).

\section{Kerala and Ayurveda Manuscripts}

Ayurveda, the Indian system of medicine, has been extremely popular in the southern Indian State of Kerala for a very long time (11). Practitioners of Ayurveda in Kerala continue to be familiar with all its eight main branches. In contemporary Kerala too, all these branches of Ayurveda continue to be popularly employed and the advent of allopathic medicines has not really diminished the popularity of Ayurvedic treatment.

The geography of Kerala, which helped to avert the attacks of foreign forces also contributed to the rich collection of Manuscripts in Kerala. Due to these conditions most of our knowledge in the forms of Manuscripts are being preserved up to an extent in Kerala, while in Northern India which witnessed a lot of wars and hence the destruction of many cultural centers and knowledge centers which preserved manuscripts in a large manner. It is worth noting that many Sanskrit manuscripts and rare manuscripts are found in Kerala or southern Tamil Nadu including the drama's of Bhasa which is considered to be the first drama written in Sanskrit (4). 
Many valuable manuscripts can be found in almost each village in Kerala, the majority of them belonging to private custodians. A survey of the 'Science Texts in Manuscript Repositories of Kerala and Tamil Nadu' was carried out by the late Dr. K.V. Sarma [Published in 2003] and he identified 1,286 Ayurveda manuscripts in Kerala. Among these, 586 are independent works and the rest are commentaries (12).

The work depends on the knowledge contained in these manuscripts, the private owners of Ayurvedic manuscripts are reluctant to part with them and hence these are seldom donated to manuscript libraries. While many such private repositories are known, information is yet to be obtained about many more. Though no firm statistics are available about the collections in private libraries, it appears that manuscripts dealing with Vishacikitsa are quite popular. A few manuscripts on Mrigacikitsa may also be available (11).

The languages employed in most manuscripts in Kerala are in Sanskrit and Malayalam, although a few in the southern region of the State are also written in Tamil. The same holds true of Ayurveda manuscripts. Of these, the Malayalam and Tamil manuscripts are in their respective language scripts. A few Ayurveda manuscripts in Malayalam are found in Vattezhuttu, an ancient script used for Tamil and Malayalam. Sanskrit manuscripts in Kerala are usually in the Grantha, Devanagari, Nandinagari, Malayalam, Kannada, Telugu, etc. scripts (13). Some of the Ayurveda manuscripts comprise Jyotisha portions also. Among the Tamil manuscripts a considerable number of manuscripts deal with the Siddha system of medicine.

Among the known Ayurvedic manuscripts found in Kerala, a few deserve special mention like the Pathya commentary by an anonymous author, the Vakyapradipika by Alattur Paramesvaran Nambi, Kairali commentary for the Uttarasthana by Pulanthol Moosad, Ashtangahridayavyakhya by Govinda Pisharoti and the Malayalam commentary Prakashika by Raghavan Thirumulpad. The Sararthadarpana commentary by Kaikkulangara Ramavariyar, the Sutikamritam and Arunodayam commentaries by Kayikkara Govindan Vaidyar, the Vasudeviya commentary by C.K. Vasudeva Sarma, Malayalam translation of the Sutrasthana by Kesavan Embranthiri, the Sarabodhini commentary by Kochusankaran Vaidyan, and the Ashtangahridayakosa by K.M. Vaidyar which provides technical terms of Ashtangahridaya, are also extremely valuable works (13).

In addition to these texts, many commentaries of the Ashtangahridaya, in different languages, are popular in Kerala, such as Kairali, Nidanachintamani, Balabodhini, Vyakhyasara, Hridaya, Uddhyota, Pathya, Sanketamanjari, Vagbhatakhandanamandanam, Vaiduryakabhasyam, Vijneyarthaprakasika, Lalita and Panchika. The Lilaplava commentary by Vasudevan Moosad, Bhaskara commentary by Uppottu Kannan and Alpabuddhiprabodhana, a Malayalam commentary by Shreekantha are some other valuable commentaries of the Ashtangahridaya. The Malayalam commentary of Ashtangahriaya, called Ashtangahridayam Bhasa is a work that deserves special mention (13).

There were many other independent works and commentaries that were composed in Kerala and that are worth noting. The Vishanarayaniya by Narayana, a 16th century work on Toxicology is one such authoritative text. The Hridayapriya by Vaikkattu Paccumoottatu is a major work that was composed in 1865 and published under the Trivandrum Sanskrit Series, No. 111. The Sukhasadhaka, written by the same author in 1881, consists of twelve khandas and is an abridged version of the Hridayapriya (13).

Vadakkeppattu Narayanan Nair's Anugrahamimamsa deals with Bacteriology. P.S. Variyar's Ashtangasharirika, which is based on Ashtangahridaya, was published in 1925 along with a Tippani called Gudarthabodhini. Another work by the same author, the Brihaccharirika, deals with human anatomy and physiology and represents an amalgam of Indian and Western systems of medicine. The Sadacharanivrittivarttana, written by Aryasarman, discusses both Ayurveda and Vedanta in seventeen chapters. The Sarvagaralapramochana, written by Kuttamattu Ramakurup, deals with the treatment of poison. Vasudeva's Yogasarasangraha explains different kinds of medicinal preparations. The Kochunni Thampuran with his own commentary, is also a noteworthy publication. The Rasatantra and the Rasamanjari, by A.R. Rajaraja Varma and Thaikkat Narayanan Moosad respectively, deals with the Rasayanatantra branch of Ayurveda (13).

The Trivandrum Oriental series is one of the oldest series in Kerala is particularly rich in Ayurveda or Indian medicine. There are manuscripts dealing with herbology together with extremely valuable dictionaries of herbs. They may also be of much use in these days of pharmaceutical research, when the increasing value of Indian herbs in the form of new drugs is being realized in centers of medicinal research the world over.(16)

\section{Efforts to Protect Manuscripts}

Conserving or documenting the manuscripts is much important to all citizens of India as manuscripts are our traditional assets. This importance is also mentioned in our constitution. The Constitution of India states, under fundamental Duties in Article 51A:"It shall be the duty of every citizen to value and preserve the rich heritage of our composite culture" (14),(17). But preservation of manuscripts and documenting it is more important to an Ayurvedic practitioner than a common citizen.

As a matter of fact, more number of Indian manuscripts are available in foreign countries than in India. This is a matter of concern as treasures of traditional information might be available in these manuscripts. These manuscripts might have reached other parts of the world through cultural exchanges or through cultural smuggling. What is shocking is that the invaluable knowledge in these manuscripts are being analyzed in these countries and its results are marketed in our own country. The recent cases fought and won by TKDL [Traditional Knowledge Digital Library] is the very best examples of such activities(15). Even though this is applicable to all traditional information, the most 
affected area is Ayurveda.

As India still have repository of large treasures in the form of non documented Manuscripts it is the duty of all especially who working in the traditional Medical system of India, to preserve this. Most of the manuscripts are available in private custody and many of these people are not aware of its value. As an Ayurveda practitioner, one can find the relevant manuscripts in Ayurvedic fields which can add up the knowledge of earlier Ayurveda tradition. Through the proper identification of manuscript, their preservation and by publication, this knowledge can be preserved and can be used for the benefits of Ayurveda and thus well being of the human being(3).

\section{Conclusion}

It is the duty of each and every citizen of India to preserve and conserve the rich heritage of India, by conserving and preserving the manuscripts. This is more relevant for an Ayurvedic research scholar as the very existence of Ayurveda largely depends on the preservation of original Ayurvedic knowledge and also in finding hidden knowledge which is much important to handle the new challenges of the present era. Even though our Government has started initiation for preservation and conservation of manuscripts, still a larger portion of manuscripts are hidden or not yet available for the public profile. So everyone in Ayurvedic research field has to take an initiative to find the Ayurveda manuscripts available in the private collection which is known to them or in their nearby areas or in the public collection and try to document it. Many manuscripts in private collection needs preservation and with the help of the oriental libraries of that region, these manuscripts can be preserved scientifically. Ayurvedic research scholars can play a crucial role for this collection and preservation of manuscripts, thus contributing to the well being of the present and future generations and also thus adding up the glory of Ayurveda.

\section{Acknowledgement}

We thank Dr. Akhilesh Shukla, Assistant professor, department of Samhita and Siddhantha, Amrita school of Ayurveda, Kollam, Kerala, for helping and giving valuable suggestions for the preparation of this article.

\section{References:}

1) Comprehensive research methodology for ayurvedic scholars, by S Suresh Babu Chaukambha Orientalia ,Varanasi, edition 2013,p 57.

2) Sreelekha KG, Deterioration of manuscripts, Journal of manuscript studies, published by Oriental Research Institute and manuscript Library,
University of Kerala, Karyavattom, Thiruvanathapuram, Vol XXXIX-2009-10 p 20-31.

3) The Antiquities and Art Treasures Act ,1972 available in http ://asi.nic.in/pdf_data/8.pdf(as assessed on 16 Jan 2016)

4) Sreelekha KG, Techniques of writing, Journal of manuscript studies, published by Oriental Research Institute and manuscript Library, University of Kerala, Karyavattom, Thiruvanathapuram, Vol XXXIX-2008. 38-43p.

5) Handbook of Medical Manuscriptology, Banglore, Foundation for Revitalization of Local Health Traditions (FRLHT), Institute of Ayurveda and Integrative Medicine (IAIM), 2010, p10.

6) National Mission for Manuscripts February 2003Project Document, NMM, 2003

7) National Mission for Manuscripts February 2003 http://namami.org/

8) Jörg Quenzer, Dmitry Bondarev, Jan-Ulrich Sobisch , Manuscript Cultures: Mapping the Field, Berlin, Walter de Gruyter GmbH \& Co KG, 12-Dec -2014 (160p)

9) Dominik Wujastyk, Sanskrit Manuscript Collections Outside India, with special reference to ${ }^{-}$Ayurveda. Presented at The National Seminar on Medical Manuscripts, Foundation for the Revitalization of Local Health Traditions, Bangalore, October 5-6, 2005

10) National Mission for Manuscripts February 2003 http://namami.org/Performance.htm

11) Jameela Beevi A, Manuscripts and Ayurveda, Journal of manuscript studies, Oriental Research Institute and manuscript Library, University of Kerala, Karyavattom, Thiruvanathapuram ,Vol XXXVIII-2007. 81-86p.

12) Sarma KV; Vempați Kuṭumbasāāstrī; Science texts in Sanskrit in the manuscripts repositories of Kerala and Tamilanadu, New Delhi, Rashtriya Sanskrit Sansthan, 2003.

13) Visalakshi $P$, The Ayurveda Tradition in Kerala, Kriti Rakshana, Feb 2007, New Delhi, National Mission of Manuscripts, (www.namami.org)

14) INDIA CODE Text Base available in http:// indiacode.nic.in

15) WIPO Magazine [World Intellectual Property Organisation], June 2011 (http://www.wipo.int/ wipo_magazine/en/2011/03/article_0002.html)

16) Raghavan pillai K, Kerala Manuscripts and Indian Culture, Journal of manuscript studies, Published by Oriental Research Institute and manuscript Library, University of Kerala, Karyavattom, Thiruvanathapuram. Vol XL-2009-10, 7-19p

17) The Constitution of India available in http:// lawmin.nic.in/olwing/coi/coi-english/coiindexenglish.htm. 